\title{
PENERAPAN PEWARNAAN GRAF UNTUK MENENTUKAN WISATA KULINER DI SAMARINDA
}

\author{
Wiwik Widiyatni ${ }^{1}$, Vilianty Rafida $^{2}$, Hanifah Ekawati Sibali ${ }^{3}$, Hannie Ardilla Kusumawati ${ }^{4}$ \\ STMIK Widya Cipta Dharma ${ }^{1,2,3,4}$ \\ Jl. M. Yamin No. 25, Samarinda, 75123 \\ Sur-el : wiwikwidiyatni82@gmail.com ${ }^{1}$,vilyrafida@gmail.com², hanifah@wicida.ac.id ${ }^{3}$, \\ ardilahanie@ymail.com ${ }^{4}$
}

\begin{abstract}
Culinary tourism in an area is usually hunted by tourists. The problem that often arises is that many restaurants are available so that it makes tourists confused to choose a restaurant and takes a long time to decide on a choice of restaurants. Therefore, we need a system and method that can be applied to recommend restaurants. The restaurant recommendation application in this study was created to assist tourists in finding restaurants with the same menu choices. The method used is the Graph Coloring Method, the application development method used is Waterfall consisting of data analysis, technology analysis, system analysis, information analysis and user analysis. The results of this study are made an application to determine which restaurants can recommend restaurants with the same menu. Users can enter the menu as they wish then the application will recommend restaurants using a simple line coloring algorithm at the point. After processing the application will be able to display the results of restaurant recommendations with the same menu.
\end{abstract}

Keywords: Culinary Tour, Restaurant, Waterfall, Graph Coloring

\begin{abstract}
Abstrak : Wisata kuliner suatu daerah biasanya pasti diburu oleh wisatawan. Masalah yang sering muncul yaitu banyak rumah makan yang tersedia sehingga membuat wisatawan kebingungan untuk memilih rumah makan dan membutuhkan waktu yang lama untuk memutuskan pilihan rumah makan. Karena itu dibutuhkan suatu sistem dan metode yang dapat diterapkan untuk merekomendasikan rumah makan. Aplikasi rekomendasi rumah makan dalam penelitian ini dibuat untuk membantu wisatawan dalam mencari rumah makan dengan pilihan menu yang sama. Metode yang digunakan adalah Metode Pewarnaan Graf, dengan metode pengembangan aplikasi yang digunakan adalah Waterfall terdiri dari analisis data, analisis teknologi, analisis sistem, analisis informasi dan analisis user. Hasil dari penelitian ini adalah dibuatnya suatu aplikasi penentuan rumah makan yang dapat merekomendasikan rumah makan dengan menu yang sama. Pengguna dapat memasukkan menu sesuai dengan keinginan kemudian aplikasi akan merekomendasikan rumah makan dengan menggunakan algoritma pewarnaan barisan sederhana pada titik. Setelah diproses maka aplikasi akan dapat menampilkan hasil rekomendasi rumah makan dengan menu yang sama.
\end{abstract}

Kata kunci: Wisata Kuliner, Rumah makan, Waterfall, Metode Pewarnaan Graf

\section{PENDAHULUAN}

Makanan merupakan salah satu kebutuhan primer dari manusia, kebutuhan akan makanan selalu meningkat karena jumlah penduduk yang semakin banyak. Masalah yang sering muncul yaitu banyak tempat makan yang tersedia sehingga membuat setiap orang kebingungan untuk memilih tempat makan dan membutuhkan waktu yang lama untuk memutuskan pilihan tempat makan. Untuk menghemat waktu yang dibutuhkan untuk menentukan tempat makan dapat digunakan sebuah rekomendasi tempat makan. Aplikasi adalah alat terapan yang difungsikan secara khusus dan terpadu sesuai kemampuan yang dimilikinya[1-4]. Aplikasi juga merupakan satu unit perangkat lunak yang dibuat untuk melayani kebutuhan akan beberapa aktivitas seperti sistem perniagaan game, 
pelayanan masyarakat, periklanan atau semua proses yang hampir dilakukan manusia[5-8].

Jika dikaitkan dengan manfaat teknologi, pada zaman sekarang ini, sangat mudah sekali bagi setiap orang untuk dapat melakukan pencarian mengenai informasi tempat makan. Sistem Rekomendasi merupakan sebuah metode untuk memberikan rekomendasi dengan memprediksi nilai sebuah item bagi seorang pengguna dan kemudian mempresentasikan item dengan nilai prediksi tertinggi[9-12]. Dengan banyaknya sumber informasi mengenai tempat makan tersebut, hal itu akan membantu masyarakat untuk mendapatkan informasi mengenai tempat makan tersebut. Akan tetapi, dengan banyaknya informasi tersebut, justru juga dapat membuat masyarakat kebingungan untuk memilih tempat makan mana yang tepat untuk dikunjungi. Akibatnya, dalam memilih suatu tempat makan, sering kali dibutuhkan waktu yang lama, sehingga ini bukanlah suatu hal yang efektif. Oleh karena itu, aplikasi rekomendasi tempat makan dapat menjadi suatu solusi yang tepat bagi setiap orang dengan memberikan berbagai macam pilihan tempat makan yang terbaik untuk dikunjungi.

Sistem rekomendasi merupakan sebuah perangkat lunak yang bertujuan untuk membantu pengguna dengan cara memberikan rekomendasi kepada pengguna ketika pengguna dihadapkan dengan jumlah informasi yang besar[13-15]. Selama beberapa dekade terakhir, sistem rekomendasi telah banyak diterapkan dengan berbagai pendekatan dan teknik baru, baik di dunia industri maupun di dunia akademis. Konsep sistem rekomendasi telah digunakan secara luas oleh hampir semua area bisnis, dimana seorang user memerlukan informasi untuk membuat suatu keputusan[16].
Adapun masalah dalam penelitian ini adalah bagaimana membuat suatu program untuk menentukan tempat makan berdasarkan pilihan menunya. Salah satu metode yang dapat digunakan untuk menyelesaikan permasalahan tersebut adalah dengan menggunakan Algoritma Pewarnaan Barisan Sederhana pada titik. Diharapkan dengan menggunakan Algoritma Pewarnaan Barisan Sederhana pada titik akan diperoleh optimasi rekomendasi yaitu kondisi dimana terjadi kombinasi terbaik untuk pasangan tempat makan dan menu secara keseluruhan untuk menentukan tempat kuliner sesuai inputan $u s e r$.

\section{METODOLOGI PENELITIAN}

Model Air Terjun (Waterfall) adalah model klasik yang bersifat sistematis, berurutan dalam membangun software[17-19]. Penelitian akan dilaksanakan melalui beberapa tahapan pengembangan waterfall sebagai berikut:

1. Analisis kebutuhan (Requirement Definition) meliputi penemuan atau mengembangkan dan menganalisis tindakan yang mungkin untuk dilakukan.

2. Desain sistem dan perangkat lunak (System and Software Design) bertujuan untuk memberikan gambaran umum kepada pemakai tentang sistem teknologi informasi yang baru.

3. Implementasi dan pengujian Unit (Implementasi and Unit Testing) mengenai proses pembuatan aplikasi dan penerapan metode yang digunakan.

4. Integrasi dan pengujian sistem (Integration and System Testing) 
merupakan tahap peralihan dari sistem yang lama ke sistem yang baru, untuk menuju ke sistem yang baru maka harus dilakukan beberapa pengujian metode pengujian yang digunakan adalah black box dan White Box.

5. Penggunaan dan pemeliharaan (Operation and Maintenance) merupakan proses penggunaan aplikasi yang telah selesai dibangun, selain itu juga tahap perawatan terhadap sistem yang telah berhasil di selesaikan pembangunannya.

Setiap tahapan dilakukan secara berurutan mulai dari langkah pertama sampai langkah terakhir, setiap langkah yang telah selesai dikerjakan harus dilakukan pengkajian ulang, tertera dalam alur penelitian.

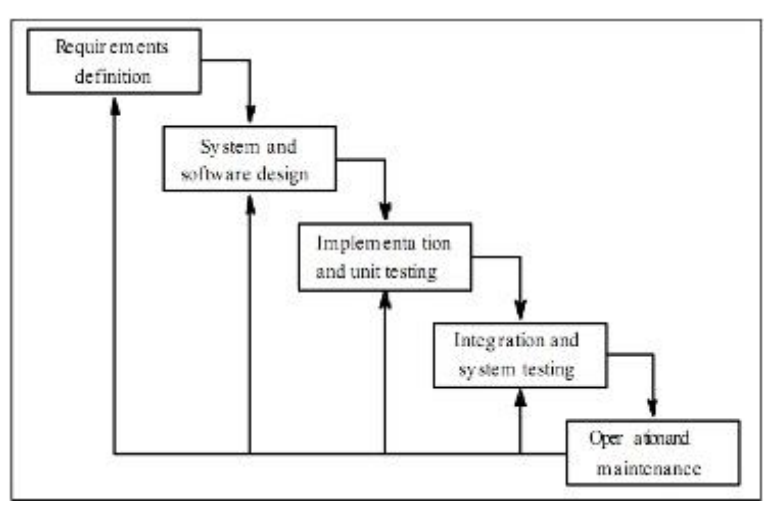

Gambar 1. Alur Penelitian

\section{HASIL DAN PEMBAHASAN}

\subsection{Proses Pewarnaan Graf}

Graf pertama kali digunakan oleh seorang matematikawan asal Swiss yang bernama Leonhard Euler untuk memecahkan masalah jembatan Konigsberg pada tahun 1736. Ia memodelkan ke bentuk graf dimana daratan sebagai vertex dan jembatan sebagai edge. Graf merupakan himpunan pasangan $(\mathrm{V}, \mathrm{E})$ dimana $\mathrm{V}$ adalah himpunan tidak kosong dari simpulsimpul (vertices) dan $\mathrm{E}$ adalah himpunan sisi (edges) yang menghubungkan sepasang simpul[20].

Proses pewarnaan graf antara vertex tempat makan dan edge jenis menu untuk menentukan tempat makan dengan menu yang sama.

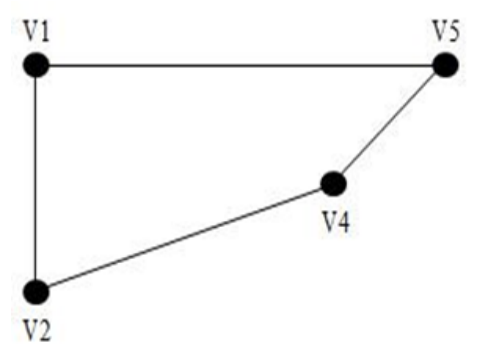

\section{Gambar 2. Graf Menu Ikan Mas Goreng}

Keterangan:

V1: Ayam Goreng Banjar

V2: Bakso Cinta Rasa

V4: Rumah Makan Magelang

V5: Rumah Makan Karya Bu Sum

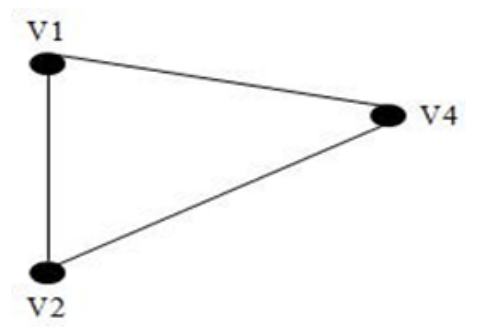

Gambar 3. Graf Menu Ayam Goreng

Keterangan:

V1: Ayam Goreng Banjar

V2: Bakso Cinta Rasa

V4: Rumah Makan Magelang

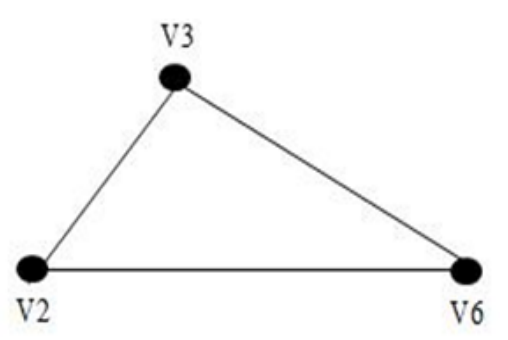

Gambar 4. Graf Menu Bakso 
Keterangan:

V2: Bakso Cinta Rasa

V3: Bakso Cak Doy

V6: Warung Gresik Suroboyo

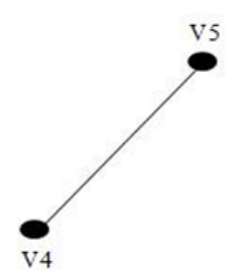

\section{Gambar 5. Graf Menu Nasi Campur}

Keterangan:

V4: Rumah Makan Magelang

V5: Rumah Makan Karya Bu Sum

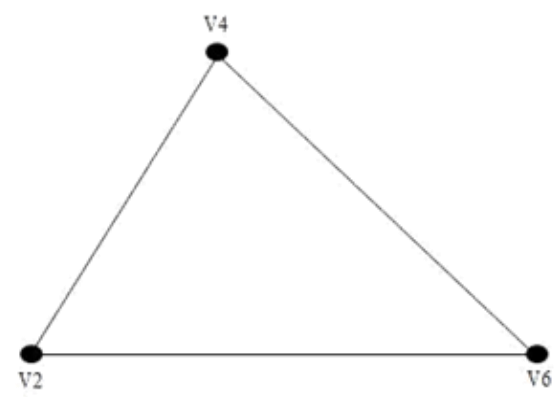

\section{Gambar 6. Graf Menu Telur}

Keterangan:

V2: Bakso Cinta Rasa

V4: Rumah Makan Magelang

V6: Warung Gresik Suroboyo

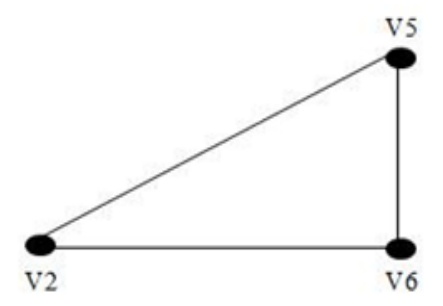

Gambar 7. Graf Menu Soto Ayam

Keterangan:

V2: Bakso Cinta Rasa

V5: Rumah Makan Karya Bu Sum

V6: Warung Gresik Suroboyo

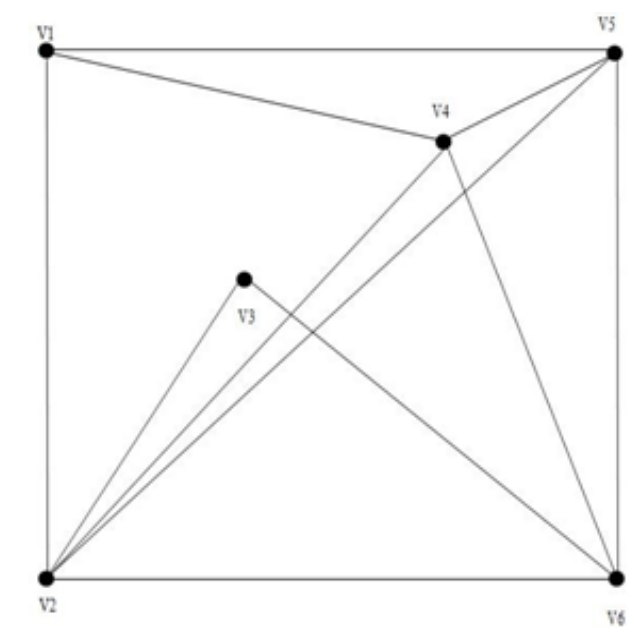

Gambar 8. Graf Tempat Makan dan Jenis

$$
\text { Menu }
$$

Keterangan:

V1: Ayam Goreng Banjar dengan menu Ikan Mas Goreng, Ayam Goreng

V2: Bakso Cinta Rasa dengan menu Ikan Mas Goreng, Bakso, Ayam Goreng, Soto Ayam

V3: Bakso Cak Doy dengan menu Bakso

V4: Rumah Makan Magelang dengan menu Ayam Goreng, Nasi Campur, Telur

V5: Rumah Makan Karya Bu Sum dengan menu Ikan Mas Goreng, Nasi Campur, Soto Ayam

V6: Warung Gresik Suroboyo dengan menu Soto Ayam, Bakso, Telur

Edge: Jenis Menu $1=$ Orange, $2=$ Abu-Abu, $3=$ Merah, $4=$ Biru, $5=$ Hitam, 6= Hijau

Diketahui:

Titik yang berhubungan langsung dengan V1 adalah V2, V4, V5

Titik yang berhubungan langsung dengan V2 adalah V1, V3, V4, V5, V6

Titik yang berhubungan langsung dengan V3 adalah V2, V6 
Titik yang berhubungan langsung dengan V4 adalah V1, V2, V5, V6

Titik yang berhubungan langsung dengan V5 adalah V1, V2, V4, V6

Titik yang berhubungan langsung dengan V6 adalah V2, V3, V4, V5

Langkah-Langkah Penyelesaian:

Step 1: Label warna yang tersedia adalah 1, 2, 3,

\section{$4,5,6$}

Step 2:

$\mathrm{C} 1=\{1\}, \mathrm{C} 2=\{1,2\}, \mathrm{C} 3=\{1,2,3\}, \mathrm{C} 4=$

$\{1,2,3,4\}, C 5=\{1,2,3,4,5\}$,

$\mathrm{C} 6=\{1,2,3,4,5,6\}$

Step 3: $\mathrm{i}=1$

Step 4: 1 adalah warna pertama di C1, Jadi warna titik V1 dengan warna 1

Step 5: Titik yang berhubungan langsung dengan titik yang

di V1 adalah V2, V4, V5

$\mathrm{C} 2=\{1,2\}-\{1\}=\{2\}$

$C 4=\{1,2,3,4\}-\{1\}=\{2,3,4\}$

$\mathrm{C} 5=\{1,2,3,4,5\}-\{1\}=\{2,3,4,5\}$

$i=1+1=2$

Step 4: V2= 2

Step 5: Titik yang berhubungan langsung dengan titik yang ada di V2 adalah V3, V5, V4, V6

$\mathrm{C} 3=\{1,2,3\}-\{2\}=\{1,3\}$

$C 5=\{2,3,4,5\}-\{2\}=\{3,4,5\}$

$\mathrm{C} 4=\{2,3,4\}-\{2\}=\{3,4\}$

$\mathrm{C} 6=\{1,2,3,4,5,6\}-\{2\}=\{1,3,4,5$,

$6\}$

$i=2+1=3$

Step 4: V3=1

Step 5: Titik yang berhubungan langsung dengan titik yang ada di V3 adalah V6

$\mathrm{C} 6=\{1,3,4,5,6\}-\{1\}=\{3,4,5,6\}$

$i=3+1=4$

Step 4: V4= 3
Step 5: Titik yang berhubungan langsung dengan titik yang

ada di V4 adalah V5, V6

$\mathrm{C} 5=\{3,4,5\}-\{3\}=\{4,5\}$

$\mathrm{C} 6=\{3,4,5,6\}-\{3\}=\{4,5,6\}$

$i=4+1=5$

Step 4: V5= 4

Step 5: Titik yang berhubungan langsung dengan titik yang ada di V5 adalah V4, V6

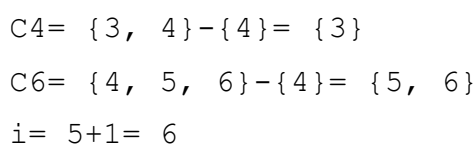

Step 4: V6= 5

Step 5: Titik yang berhubungan langsung dengan titik yang ada di V6 adalah V3, V5

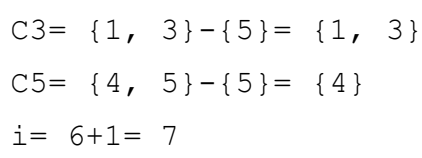

Step 5: Hasil i lebih dari banyaknya titik yang ada pada graf maka lanjut pada step 6 Tabel titik-titik $\mathrm{G}$ dan warnanya

Tabel 1. Hasil Pewarnaan

\begin{tabular}{ccccccc}
\hline V $(\mathrm{G})$ & $\mathrm{V} 1$ & $\mathrm{~V} 2$ & $\mathrm{~V} 3$ & $\mathrm{~V} 4$ & $\mathrm{~V} 5$ & $\mathrm{~V} 6$ \\
\hline Warna & 1 & 2 & 1 & 3 & 4 & 5 \\
\hline
\end{tabular}

Hasil dari pewarnaan graf sebagai berikut:

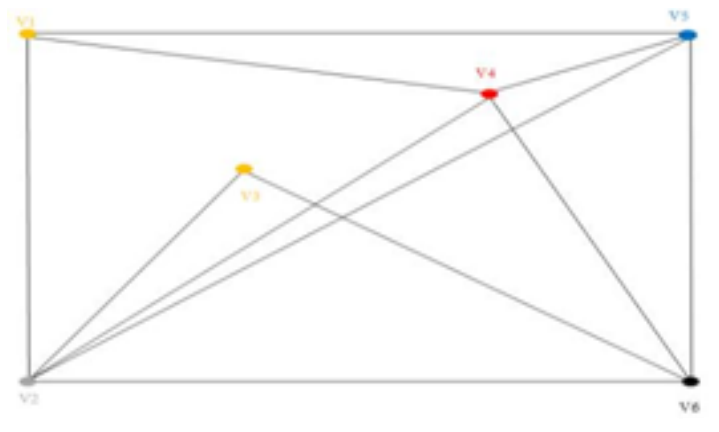

\section{Gambar 9. Hasil Pewarnaan Graf}

Pada gambar 9 adalah hasil dari pewarnaan antara vertex tempat makan dan edge menu. Adapun hasil dari pewarnaan graf untuk rekomendasi tempat makan sesuai dengan menu 
yang ditawarkan yaitu ada 5 warna yang didapatkan pada gambar 9, 5 warna yang didapatkan pada graf $\mathrm{G}$ pada rekomendasi ini digunakan untuk menentukan menunya. Jadi, 5 warna adalah 5 tempat makan yang mempunyai menu yang sama. Untuk rekomendasi tempat makan ini, pada warna yang sama maka tempat makan tersebut mempunyai menu yang berbeda.

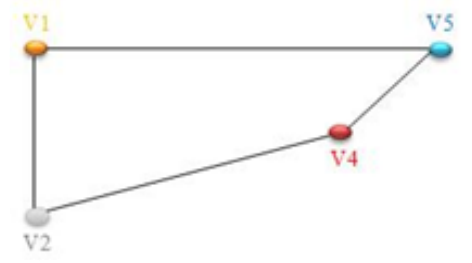

\section{Gambar 10. Hasil Pewarnaan Graf Menu} Ikan Mas Goreng

Pada gambar 10 adalah hasil dari pewarnaan antara vertex: ayam goreng banjar, bakso cinta rasa, rumah makan magelang, rumah makan karya bu sum dan edge: menu ikan mas goreng.

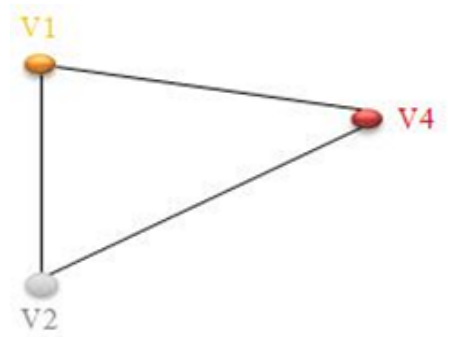

\section{Gambar 11. Hasil Pewarnaan Graf Menu} Ayam Goreng

Pada gambar 11 adalah hasil dari pewarnaan antara vertex: ayam goreng banjar, bakso cinta rasa, rumah makan magelang dan edge: menu ayam goreng.

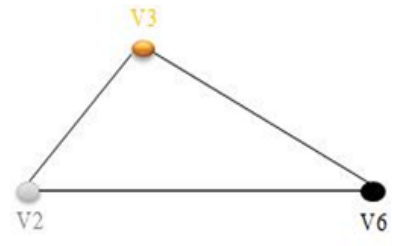

Gambar 12. Hasil Pewarnaan Graf Menu Bakso
Pada gambar 12 adalah hasil dari pewarnaan antara vertex: bakso cinta rasa, bakso cak doy, warung gresik suroboyo dan edge: menu bakso.

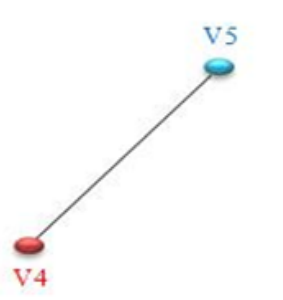

\section{Gambar 13. Hasil Pewarnaan Graf Menu}

\section{Nasi Campur}

Pada gambar 13 adalah hasil dari pewarnaan antara vertex: rumah makan magelang, rumah makan karya bu sum dan edge: menu nasi campur.

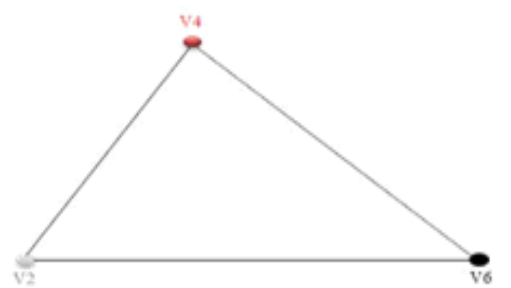

\section{Gambar 14. Hasil Pewarnaan Graf Menu} Telur

Pada gambar 14 adalah hasil dari pewarnaan antara vertex: bakso cinta rasa, rumah makan magelang, warung gresik suroboyo dan edge: menu telur.

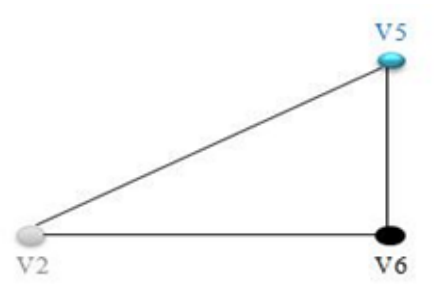

\section{Gambar 15. Hasil Pewarnaan Graf Menu} Soto Ayam

Pada gambar 15 adalah hasil dari pewarnaan antara vertex: bakso cinta rasa, rumah makan karya bu sum, warung gresik suroboyo dan edge: menu soto ayam. 
Tabel hasil rekomendasi adalah sebagai berikut:

Tabel 2. Hasil Rekomendasi

\begin{tabular}{cll}
\hline \multirow{2}{*}{ Menu } & \multicolumn{1}{c}{ Tempat Makan } & Alamat \\
& Ayam Goreng Banjar & Jl. P. Antasari No.22 \\
Ikan & Bakso Cinta Rasa & Jl. A. Yani \\
Mas & Rumah Makan Karya Bu & Jl. Kini Balu No. 14 RT. \\
Goreng & Sum & 07 \\
& Rumah Makan Magelang & Jl. KH. Ahmad Dahlan \\
& Ayam Goreng Banjar & No. 8 RT. 37 \\
Ayam & Bakso Cinta Rasa & Jl. A. Yant \\
Goreng & Rumah Makan Magelang & Jl. KH. Ahmad Dahlan \\
& & No. 8 RT. 37 \\
& Bakso Cak Dov & Jl. Wahid Hasyim II RT. \\
Bakso & Bakso Cinta Rasa & 05 \\
& Warung Gresik Suroboyo & Jl. Arief Rahman Hakim \\
& Rumah Makan Magelang & Jl. KH. Ahmad Dahlan \\
Nasi & & No. 8 RT. 37 \\
Campur & Rumah Makan Karya Bu & Jl. Kini Balu No. 14 RT. \\
& Sum & 07 \\
& Bakso Cinta Rasa & Jl. A. Yani \\
Telur & Rumah Makan Magelang & Jl. KH. Ahmad Dahlan \\
& & No. 8 RT. 37 \\
& Warung Gresik Suroboyo & Jl. Arief Rahman Hakim \\
& Bakso Cinta Rasa & Jl. A. Yani \\
& Rumah Makan Magelang & Jl. KH. Ahmad Dahlan \\
& Warung Gresik Suroboyo & No. 8 RT. 37 \\
& &
\end{tabular}

\subsection{Tampilan Halaman}

Gambar 16 tampilan halaman menu utama pada aplikasi rekomendasi tempat makan pada Dinas Pariwisata Samarinda. Terdapat Button Master, Button Rekomendasi dan Button Keluar.

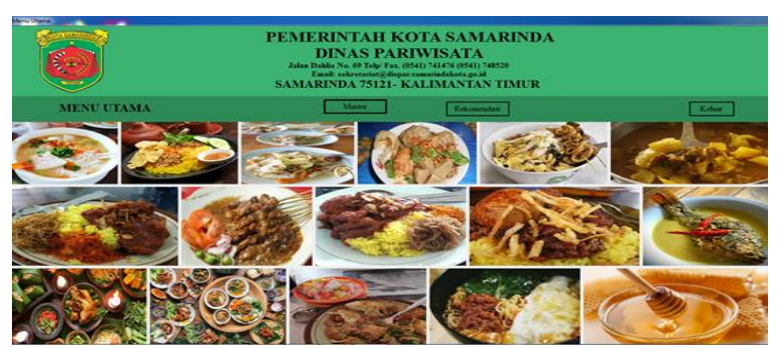

Gambar 16. Halaman Utama

Gambar 17 merupakan tampilan halaman login. Akan dimasukkan data akun yaitu username dan password. Jika akun benar maka aplikasi masuk ke halaman master, dan jika salah maka akan kembali diminta untuk memasukkan akun yang benar.

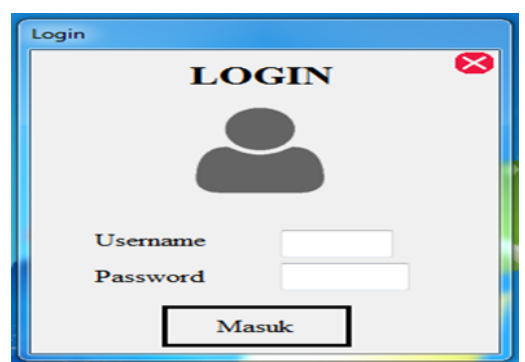

Gambar 17. Halaman Login

Gambar 18 tampilan halaman master pada aplikasi rekomendasi tempat makan pada Dinas Pariwisata Samarinda. Terdapat Button Data Tempat Makan, Button Data Menu dan Button Keluar.

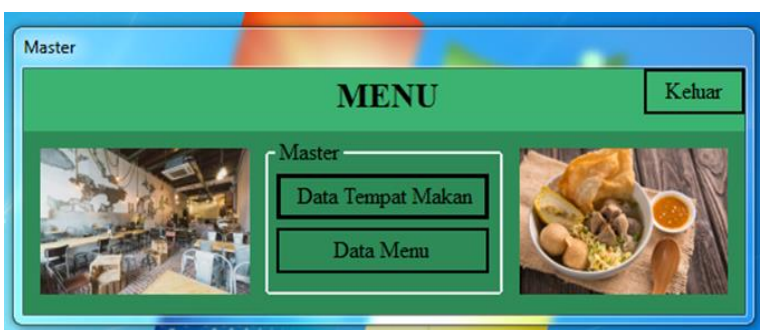

Gambar 18. Halaman Master

Pada halaman tempat makan admin dapat melihat data tempat makan yang sudah ada. Pada halaman ini terdapat textbox cari data sehingga admin dapat lebih mudah untuk mencari data atau melihat data yang diinginkan, juga terdapat Button Tambah untuk menambah data, Button Ubah untuk mengubah data, Button hapus untuk menghapus data dan Button Keluar untuk kembali ke halaman menu utama.

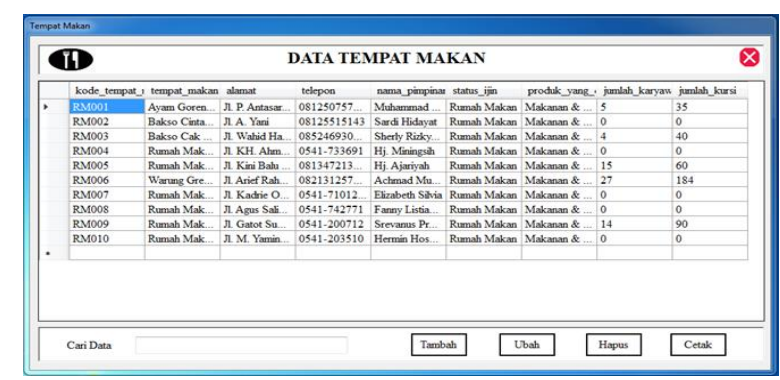

Gambar 19. Halaman Tempat Makan

Gambar 19 dan 20 merupakan halaman input tempat makan. Pada halaman ini digunakan untuk menambah atau mengubah data tempat 
makan. Terdapat Button Batal untuk kembali ke halaman tempat makan dan Button Simpan untuk menyimpan data tempat makan.

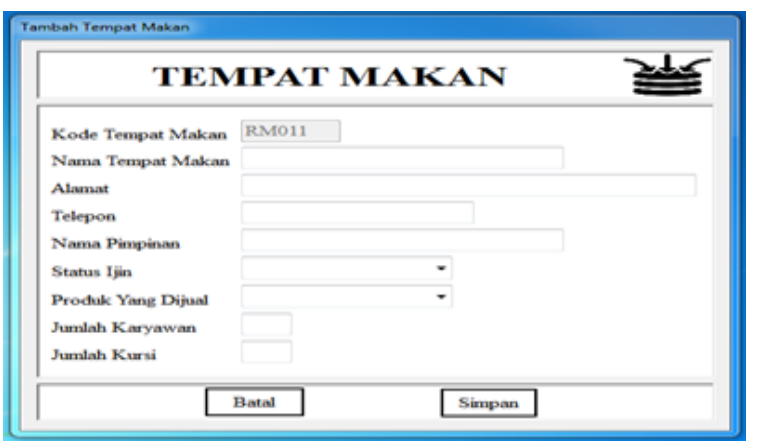

Gambar 20. Halaman Tambah Tempat

\section{Makan}

Pada halaman daftar tempat makan pada gambar 21, admin dapat melihat data tempat makan yang sudah ada. Pada halaman ini terdapat textbox cari data sehingga admin dapat lebih mudah untuk mencari data atau melihat data yang diinginkan, juga terdapat Button Lihat untuk melihat daftar menunya dan Button Keluar untuk kembali ke halaman menu utama.

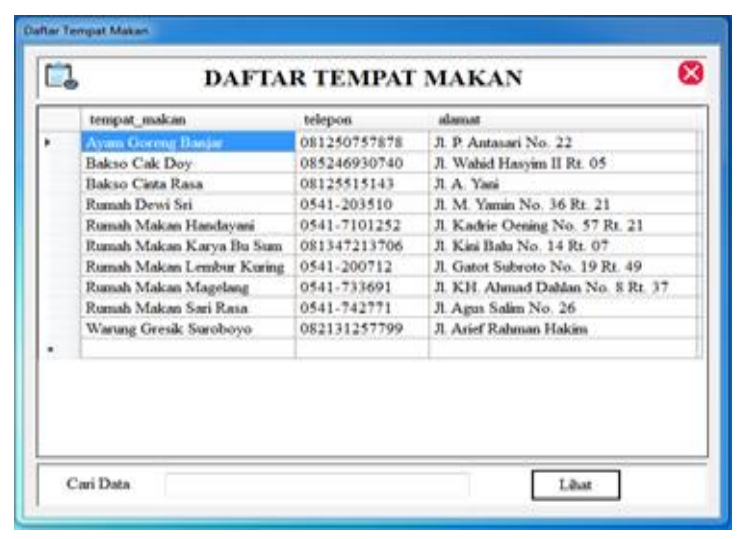

Gambar 21. Halaman Daftar Tempat Makan

Gambar 22 merupakan halaman untuk admin melihat data menu yang sudah ada, juga terdapat Button Tambah untuk menambah data, Button Ubah untuk mengubah data, Button Hapus untuk menghapus data dan Button Keluar untuk kembali ke halaman daftar tempat makan.

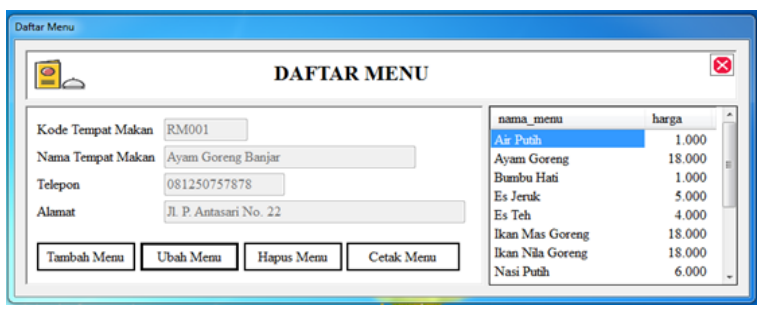

Gambar 22. Halaman Daftar Menu

Untuk menambah atau mengubah data menu dapat dilakukan pada halaman tambah menu sperti pada gambar 23. Terdapat Button Batal untuk kembali ke halaman daftar menu dan Button Simpan untuk menyimpan data menu.

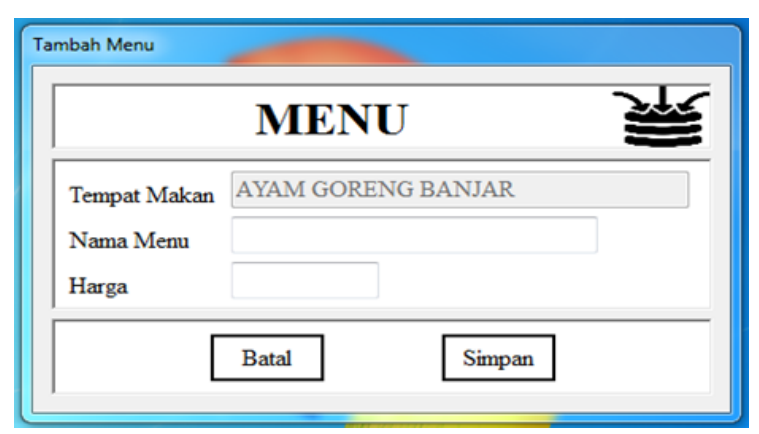

Gambar 23. Halaman Tambah Menu

Gambar 24 menunjukkan halaman cari menu. Pada halaman ini user memasukkan nama menu yang diinginkan. Terdapat Button Proses untuk memproses pencarian tempat makan yang mempunyai menu dari inputan user dan Button Keluar untuk kembali ke halaman menu utama.

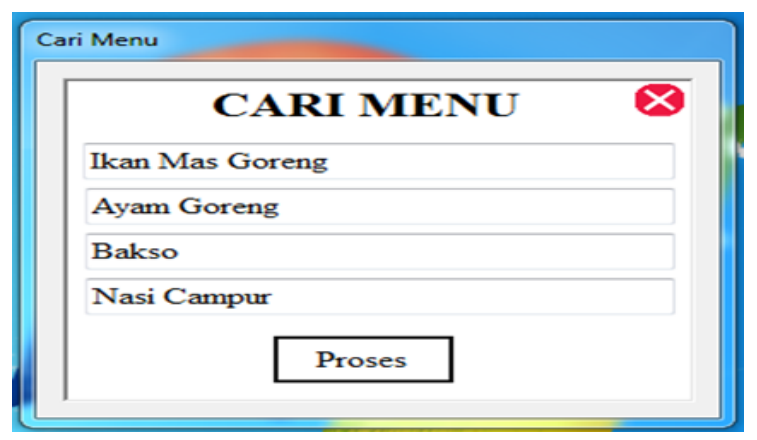

Gambar 24. Halaman Cari Menu

Pada gambar 25 menunjukkan halaman bagi user dapat melihat hasil rekomendasi tempat makan. Terdapat Button Lihat Menu 
untuk melihat daftar menunya dan Button Keluar untuk kembali ke halaman Cari Menu.

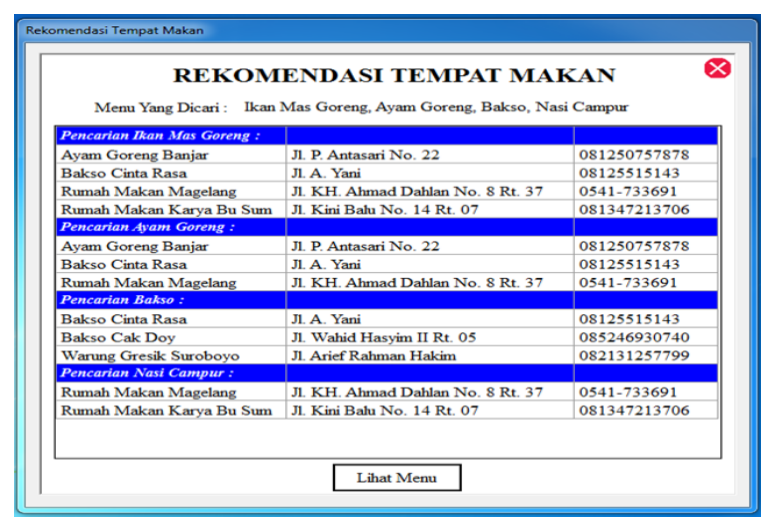

Gambar 25. Halaman Rekomendasi Tempat

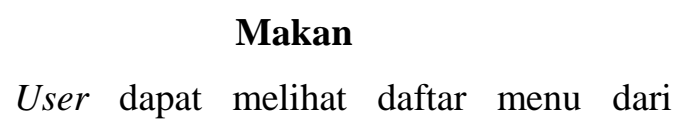
tempat makan yang direkomendasikan seperti terlihat pada gambar 26. Terdapat Button Keluar untuk kembali ke halaman Rekomendasi Tempat Makan.

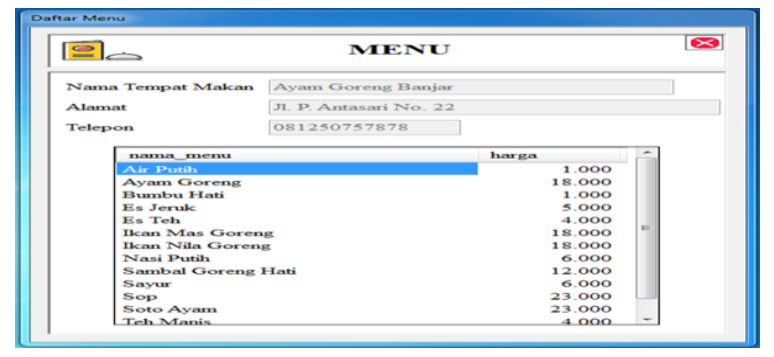

Gambar 26. Halaman Menu Tempat Makan

\section{Yang Direkomendasikan}

Gambar 27 merupakan tampilan halaman cetak data tempat makan pada Dinas Pariwisata Samarinda.

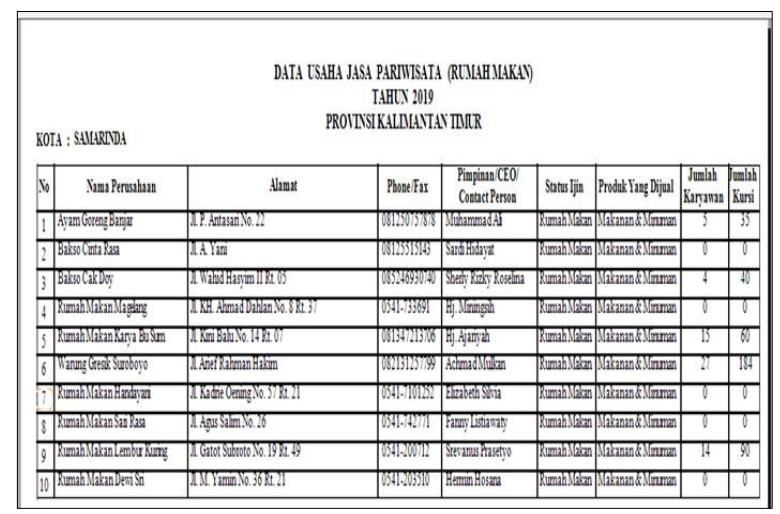

Gambar 27. Cetak Data Tempat Makan
Gambar 28 merupakan tampilan halaman cetak data menu pada Dinas Pariwisata Samarinda.

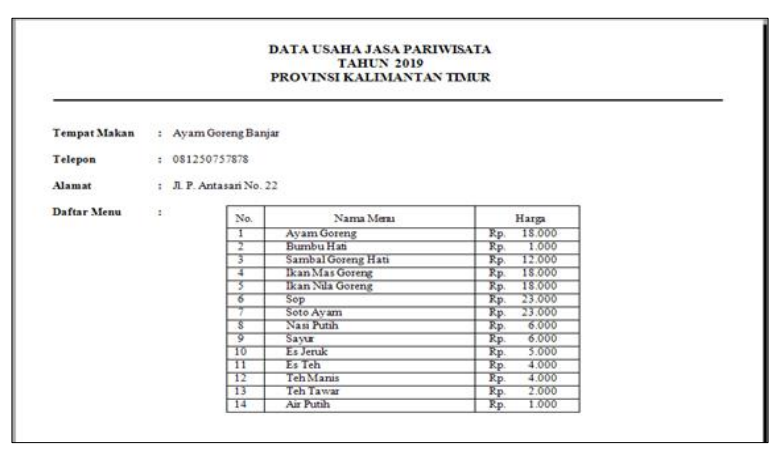

Gambar 28. Cetak Data Menu

\section{KESIMPULAN}

Penerapan metode pewarnaan pada graf untuk melakukan rekomendasi tempat makan pada Dinas Pariwisata Samarinda dengan menggunakan metode pengembangan aplikasi yaitu Model Air Terjun (Waterfall). Dengan menerapkan metode pewarnaan graf untuk rekomendasi tempat makan pada Dinas Pariwisata Samarinda maka rekomendasi dapat dilakukan lebih mudah dan dapat menghemat waktu yang dibutuhkan dalam pencarian tempat makan.

Admin dalam hal ini Dinas Pariwisata Samarinda untuk mengolah data dalam proses rekomendasi tempat makan. User dalam hal ini Konsumen untuk mencari tempat makan berdasarkan pilihan menuya.

\section{UCAPAN TERIMA KASIH}

Direktorat Riset dan Pengabdian Masyarakat Direktorat Jenderal Penguatan Riset dan Pengembangan Kementerian Riset dan Teknologi/ Badan Riset dan Inovasi Nasional 
sesuai dengan Kontrak Penelitian Tahun Anggaran 2020.

\section{DAFTAR PUSTAKA}

[1] Agusteriansyah, B. Aplikasi Penilaian Kinerja Dosen Manajemen Informatika Menggunakan Metode Balance Scorecard. 2018.

[2] Andini, T. D., \& Zulkarnain, A. Suggestions Friends Engine Berbasis Hybrid Recommender System Untuk Mendapatkan Rekomendasi Teman Terbaik Pada Web Jejaring Sosial. 2013.

[3] Dewi, F. K. S. Pembangunan Perangkat Lunak Pembangkit Jadwal Kuliah dan Ujian Dengan Metode Pewarnaan Graf. 2010.

[4] Ferdiansyah, M. S., Jasri, M., \& Widjianto, W. Aplikasi Quick Response Dalam Melayani Pengaduan Kerusakan Sarana Stt Nurul Jadid Berbasis Android dan Web. 2016.

[5] Hengky, W. P. Aplikasi Inventory Berbasis Access 2003. Jakarta: PT. Elex Media Komputindo. 2010.

[6] Kaswidjanti, W. Implementasi Fuzzy Inference System Metode Tsukamoto Pada Pengambilan Keputusan Pemberian Kredit Pemilikan Rumah. 2014.

[7] Moenir, A., \& Yuliyanto, F. Perancangan Sistem Informasi Penggajian Berbasis Web dengan Metode Waterfall pada PT. Sinar Metrindo Perkasa (Simetri). 2017.

[8] Munir, R. Matematika Diskrit. Bandung: Informatika. 2012.

[9] Perdana, N. G., \& Widodo, T. Sistem Pendukung Keputusan Pemberian Beasiswa Kepada Peserta Didik Baru Menggunakan Metode TOPSIS. 2013.

[10] Rochmah, A. Perancangan Fitur Rekomendasi Film Di Website Solo Movie Dengan Menggunakan Metode Algoritma Apriori. 2010.
[11] Rohayah, S., Sasmito, G. W., \& Somantri, O. Aplikasi Steganografi Untuk Penyisipan Pesan. 2015.

[12] Rozi, N. F., Siahaan, D. O., \& Baskoro, F. Perbaikan Metode Rekomendasi Diskusi Pemrograman dengan Normalisasi Identifier Menggunakan Lingua IdSplitter. 2016.

[13] Rusmala dan Hamrul, H. Pembangunan Sistem Penjadwalan Kuliah Menggunakan Algoritma Pewarnaan Graf. 2011.

[14] Sari, N. R. Penerapan Metode Pewarnaan Graf Untuk Penjadwalan Mata Kuliah Pada STMIK Widya Cipta Dharma Samarinda. 2019.

[15] Sommerville. Software Engineering. Jakarta: Erlangga. 2010.

[16] Sutabri, T. Analisis Sistem Informasi. Yogyakarta: Andi. 2012

[17] Utama, D., Johar, A., \& Coastera, F. F. Aplikasi Pemesanan Makanan Dan Minuman Restaurant Berbasis Client Server Dengan Platform Android Dan Php Menggunakan Metode Centralized Dbms Architecture. 2016.

[18] Utama, W. V. Aplikasi Pengolahan Data Alat Tulis Kantor Pada Staff Operasi Komando Daerah Militer II Sriwijaya. 2014.

[19] Wijayanti, N. P. Aplikasi Pengolahan Data Pasien Rawat Jalan dan Rawat Inap Pada Rumah Sakit Khusus Paru-Paru Palembang. 2018.

[20] Yannuansa, N dan Ramadhani, R. Penggunaan Graf Dalam Penjadwalan Perkuliahan Teknik Elektro Universitas Hasyim Asy'Ari. 2018. 